\title{
The use of Ender nail in intertrochanteric fractures supported with external fixation
}

\author{
İntertrokanterik kırıklarda Ender çivilerinin eksternal fiksatörle desteklenmesi
}

\author{
Cemil ERTÜRK, ${ }^{1}$ Bilal ÇAĞMAN, ${ }^{2}$ Mehmet Akif ALTAY, ${ }^{1}$ Ŭ̆ur Erdem IŞIKAN ${ }^{1}$
}

\section{BACKGROUND}

Intramedullary Ender nailing in intertrochanteric fractures was very popular in the past. However, this method has fallen in favor over time, due to complications. The purpose of this study was to evaluate results with this method and possible ways to prevent these complications, including the use of unilateral fixators to support the Ender nails.

\section{METHODS}

This technique (Ender nailing and external fixator) was used in 39 patients $(17 \mathrm{M} / 22 \mathrm{~F}$, mean age: 71.4 years). The preoperative mean American Society of Anesthesiologists (ASA) score was 1.84 (range: 1-4) for all the patients. $\mathrm{AO} /$ OTA classification of fractures was used. In our surgery, we used an external fixator to support the intramedullary nails. All patients were evaluated with Parker-Palmer mobility score and with the Harris hip score.

\section{RESULTS}

The follow-up period was 29.2 months (20-56). Two patients experienced nail migration in the knees, two patients had varus deformation with a reduction in length of $2 \mathrm{~cm}$, and seven patients developed pin-track infection. The average Harris score and Parker-Palmer score of the 14 patients who presented for their last follow-up examination were 64 and 6.8 , respectively.

\section{CONCLUSION}

This method demonstrated several advantages, in that it allows the patient to put weight on the extremity after a shorter period of time and enables the fracture to heal rapidly without any serious complications.

Key Words: Ender nails; external fixators; fracture fixation; hip fractures.

\begin{abstract}
AMAÇ
İntertrokanterik kırıklarda intramedüller Ender çivileme, geçmiş yıllarda çok yaygındı. Ancak bu yöntemin kullanımı, komplikasyonlarından dolayı zaman içerisinde azaldı. Bu çalışmanın amacı, tek yanlı eksternal fiksatörle desteklenen Ender çivileme ile bu tür komplikasyonların önlenmesi ile birlikte bu yöntemin sonuçlarını değerlendirmektir.
\end{abstract}

\section{GEREÇ VE YÖNTEM}

Bu teknik 39 hastada kullanıldı (17 erkek, 22 kadın; ortalama yaş 71,4 yıl). Ameliyat öncesi tüm hastaların ortalama American Society of Anesthesiologists (ASA) skoru 1,84 (dağılım, 1-4) idi. Kırıklar AO/OTA sınıflamasına göre ayrıldı. Biz ameliyatımızda eksternal fiksatörü intramedüller çivilere destek amacıyla kullandık. Son takipte, tüm hastalar Parker-Palmer mobility skoru ve Harris kalça skoru ile değerlendirildi.

\section{BULGULAR}

Ortalama izlem süresi 29,2 ay (20-56) idi. İki hastada Ender çivilerinin dizden dişarı çıkması, iki hastada $2 \mathrm{~cm} \mathrm{k1-}$ salıkla birlikte varus deformitesi ve yedi hastada çivi dibi enfeksiyonu oluştu. Yaşamını sürdürebilen ve son takibi yapılabilen 14 hastanın ortalama Harris kalça skoru 64, Parker-Palmer skoru 6,8 idi.

\section{SONUÇ}

$\mathrm{Bu}$ yöntemin, herhangi bir ciddi sorun görülmeksizin, k1rığıı kısa sürede iyileşmesini sağlaması ve ekstremitesine tam ağırlık vermesine uygun olması gibi üstünlükleri gösterilmiştir.

Anahtar Sözcükler: Ender çivileri; eksternal fiksatörler; kırık tespiti; kalça kırıkları.
Department of Orthopedics and Traumatology, Harran University Faculty
of Medicine, Şanlıurfa; ${ }^{2}$ Department of Orthopedics and Traumatology, Av. Cengiz Gökçek State Hospital, Gaziantep, Turkey.
${ }^{1}$ Harran Üniversitesi Tıp Fakültesi, Ortopedi ve Travmatoloji Anabilim Dalı, Şanlıurfa; ${ }^{2}$ Av. Cengiz Gökçek Devlet Hastanesi, Ortopedi ve Travmatoloji Kliniği, Gaziantep.

Correspondence (İletişim): Cemil Ertürk, M.D. Harran Üniversitesi Tıp Fakültesi Ortopedi ve Travmatoloji Anabilim Dalı, 63300 Şanlıurfa, Turkey. Tel: +90 - 414 - 3141170 e-mail (e-posta): erturkc@yahoo.com 
Treatment of intertrochanteric fractures should aim to mobilize the patient quickly, to reduce mortality and hospitalization time, and to restore the patient's functions as much as possible. ${ }^{[1-5]}$ While stable intertrochanteric fractures can be treated efficiently, unstable fractures pose serious and stressful problems. In the surgical treatment of intertrochanteric fractures, endoprosthesis and external fixators are used in conjunction with methods such as rigid pinplates, sliding plate compression pins and screws, osteotomy and osteosynthesis plates, and intramedullary nails. ${ }^{[1-5]}$ The advantages of Ender nails include: reduction in mortality rates, less blood loss, minimal surgical trauma, and a shorter duration of time in surgery. ${ }^{[6-9]}$ Ender nails have been used in almost 12,000 cases in Europe; however, the technique has not been as popular in North America. ${ }^{[2]}$ Despite their advantages, the rotational stability of Ender nails is weak. ${ }^{[2,10-12]}$ In order to prevent complications that occurred in the past (including the loss of initial reduction resulting from surgery, the penetration and perforation of the proximal femur by the nails, external rotation, distal nail migration, and/or reduction in femur length resulting from surgery), we attempted to counteract or minimize the insufficient rotation and axial resistance of the Ender nails by supplementing them with unilateral external fixators in the six-week period after surgery.

We planned in this study to analyze the effectiveness of this combination in cases of intertrochanteric fractures.

\section{MATERIALS AND METHODS}

Written informed consent was obtained from all patients, and the study was approved by the Local Ethical Committees. We proceeded by selecting a younger control group of patients with a higher life expectancy rather than an elderly group with a higher risk of deterioration. Our age indication, like that of Barrios et al., ${ }^{[6]}$ was confined to patients aged 50 years or older with usually simple fall.

We used Ender nails and unilateral external fixators simultaneously in 39 patients with non-pathological closed intertrochanteric fractures who were seen in our clinic from 2003 to 2009. This group was comprised of 22 women and 17 men, ranging in age from 49 to 93 years, with a mean of 71.4 years. Of the 39 patients, 18 fractured their right and 21 their left hip. Thirty-four of the fractures were due to simple falls and 5 were due to traffic accidents. Seventeen patients $(43 \%)$ had a pre-existing associated pathology, and 4 had $\geq 2$ comorbidities. Eight of the patients had cardiovascular issues, 5 had diabetes mellitus, 4 had pulmonary issues, 3 suffered from anemia, and 1 had hemiplegic sequela. The preoperative mean American
Society of Anesthesiologists (ASA) score ${ }^{[13]}$ for all the patients was 1.84 (range: 1-4).

Only patients with a minimum follow-up of 12 months were included. The geometry and degree of bone comminution were graded using admission radiographs according to the Orthopedic Trauma Association's (OTA) classification ${ }^{[2]}$ from type A to C.

All of the fractures were closed (Fig. 1). All of the patients were given epidural anesthesia. After attaining closed reduction with observation through a scoping device and using a traction table, firstly reduction was achieved with Ender nails, then internal fixation was reinforced with unilateral external fixators. In other words, we first performed reduction with intramedullary Ender nails to provide the alignment, and then an external fixator was added for additional stabilization.

\section{Surgical Technique}

In all the cases, a longitudinal incision was made $3-4 \mathrm{~cm}$ from the proximal adductor tubercle, and a window was opened in the bone using the awl. The number of Ender nails (Ender type intramedullary nail; Hipokrat Inc., Izmir, Turkey) varied according to the width of the patient's femur medullary canal: 37 patients had two Ender nails inserted and 2 patients had 3 Ender nails inserted. Two or three Shanz pins were then applied to the femoral neck (Fig. 2). Unilateral external fixators (Hipofix Dynamic axial fixator;

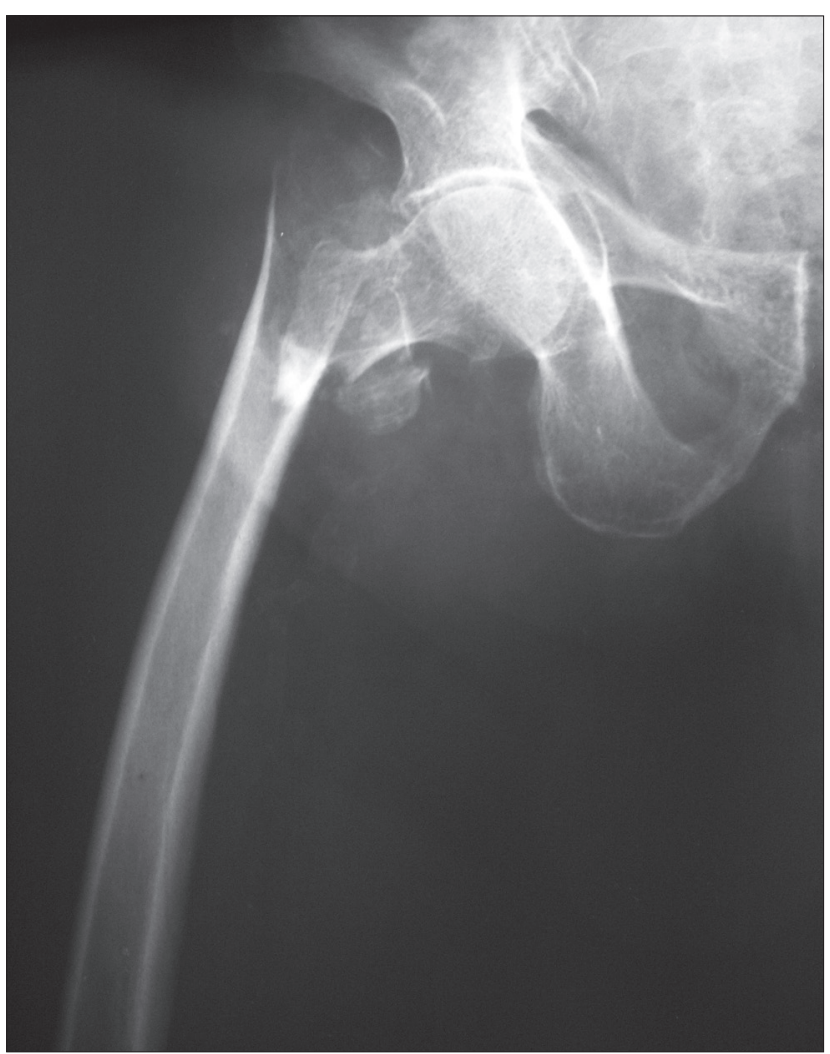

Fig. 1. Right hip unstable intertrochanteric fracture. 
Hipokrat Inc., Izmir, Turkey) were applied by affixing two Shanz pins to the diaphysis of the femur.

Patients were able to sit up in bed the day after surgery and could walk with two crutches, with full weight exerted on the legs. After discharge, patients had to present for follow-up twice a month for up to two months. After callused tissue was seen on X-rays, patients were able to walk with a single crutch (Fig. 3). After removing the external fixator from the femur bone, intramedullary biomechanical support persisted.

Fixators were removed after six weeks, either with local anesthesia or sedoanalgesia. Fracture healing was evaluated by standard radiographic projections, and union was defined as a dense callus bridging at the fracture site. Axial displacement and shortening were assessed from the radiographs. Rotational deformities and an insufficient length to measure the distance between the medial malleolus and the anterior/superior spina iliaca were judged clinically. The Ender nails were not removed unless they caused complications. After the external fixators were removed, the condition of the patients was monitored in monthly follow-up exams. At the last follow-up, patients were evaluated according to Parker-Palmer mobility score ${ }^{[14]}$ and with the Harris hip score. ${ }^{[15]}$ The Parker-Palmer mortality score evaluates the patients on the basis of their ability to walk within their place of residence, their ability to walk outside, and their ability to go shopping. Each

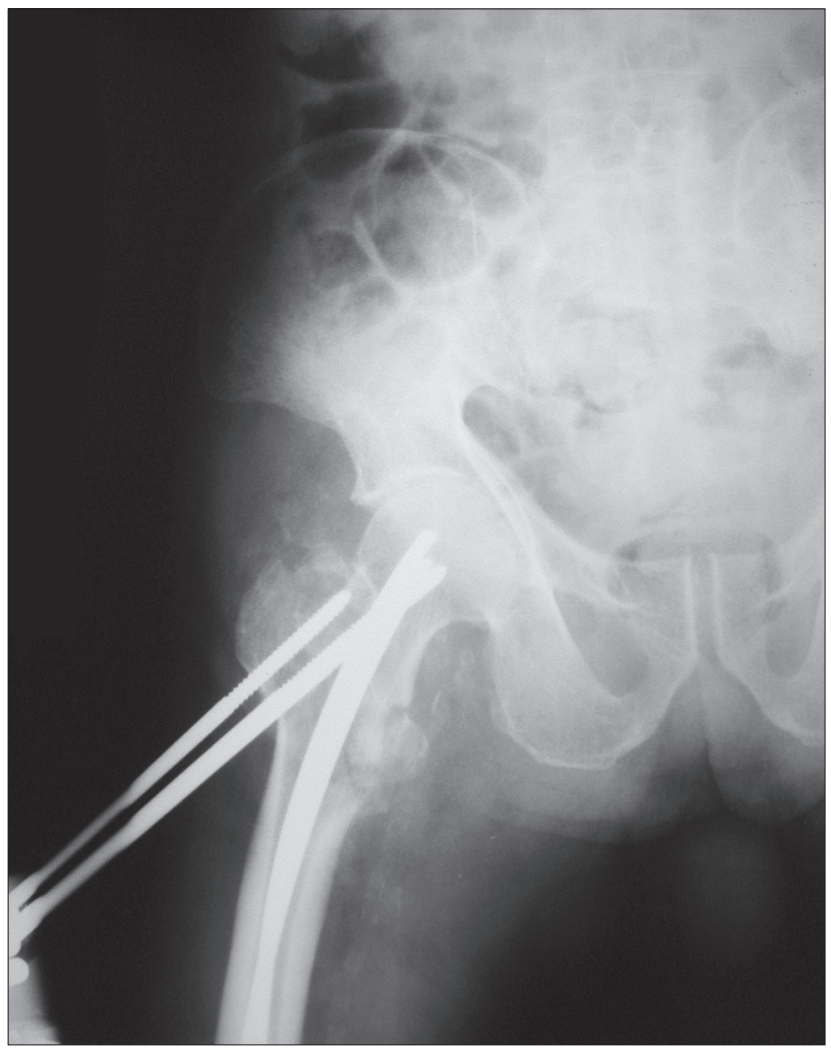

Fig. 2. X-ray of patient six weeks later. activity was assigned a score on the basis of its level of difficulty: 3 points indicated that the patient had no difficulty; 2 points indicated that the patient needed a cane or other aid; 1 point indicated that the patient needed help from another person; and 0 points indicated that the activity was impossible for the patient to perform.

\section{RESULTS}

The average follow-up period was 29 months (range: 20-56 months). The average hospitalization period was an average of 7 days (range: 5-18 days). The average duration of surgery was 60 minutes. None of the patients required open surgery or blood transfusions. In the six-week period following surgery, 7 of the patients $(18 \%)$ developed pin-track infections. Six of these pin-track infections were surface infections that responded to oral antibiotic therapy; 1 patient developed a deep infection. In this case, the external fixators were removed without waiting for the response of the more conservative treatment because the patient had also developed an intramedullary infection in the hip. Four weeks after surgery, the external fixator was removed from this patient. No further infections were found in the patient thereafter.

Thirty-three of the patients $(85 \%)$ were over 60 years old. The average postoperative period was 3 days (range: 2-6 days). The average healing pe-

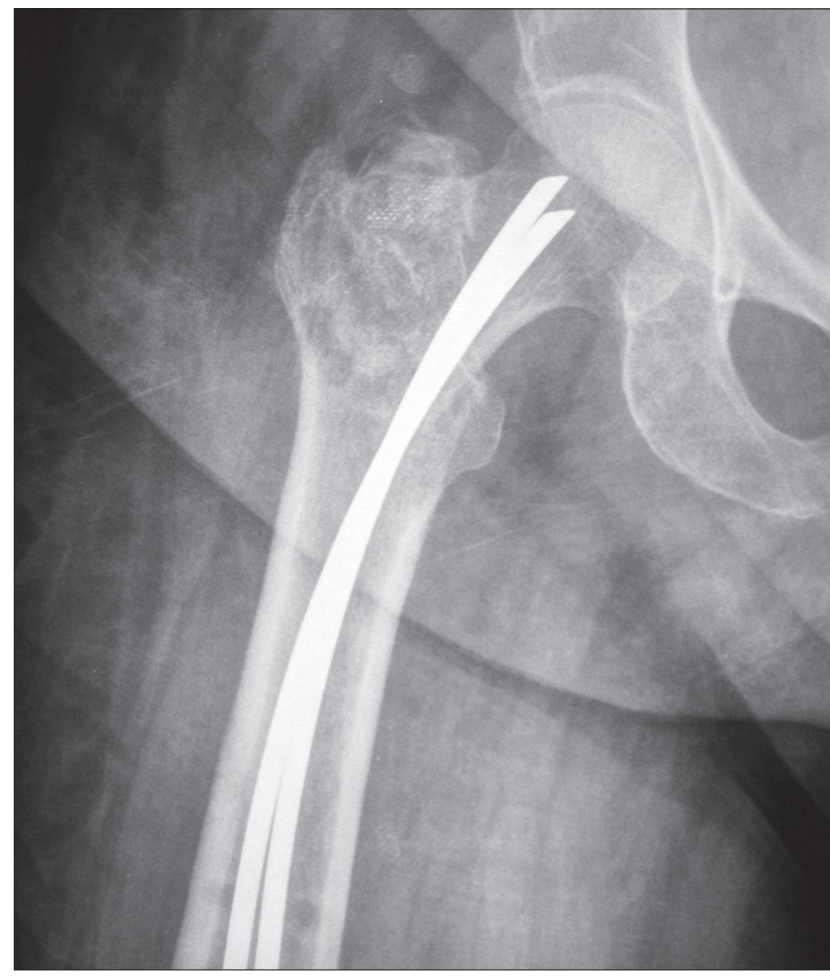

Fig. 3. Hip graph was seen after removal of external fixator. Ender pins in the hip were not removed, unless they caused problem. 
riod was 9.2 weeks (range: $8-16$ weeks). There was no delayed healing or nonunion. Two of the patients developed varus deformities in the early stages. Because the Ender nails were not applied sufficiently, the fixation was inadequate, resulting in a varus slippage $(5 \%)$. These were analyzed as technical errors. In these patients, shortenings of $2 \mathrm{~cm}$ were measured $(5 \%)$. External rotation failure occurred in 1 patient. In 2 of the patients (5\%), the Ender nails were removed because of irritations that developed in the knee during the follow-up period. In these patients, the external fixator had been removed previously. Ender nails were removed from the thigh when the fractures demonstrated union. After removal of the Ender nails, the patients had no complaints. The other patients had no complaints regarding their hips.

Postoperative mortality was observed in 1 patient due to pulmonary embolism in the intensive care unit on the second postoperative day. Within the first 2 years, 6 of the patients (15\%) died. Seven patients died after 2 years. Two patients had additional surgery (endoprosthesis). We were unable to contact 7 of the patients, but we determined that 16 of the patients were still alive. Of these, 14 presented for their last check-up; 2 were bedridden at home. None of the 14 patients who presented for their final examination had any complaints, and all had returned to their original level of function. The average Harris score and the average Parker-Palmer score of the 14 patients at the time of the most recent follow-up were 64 (range: 4482 ) and 6.8 (range: 5-8), respectively.

\section{DISCUSSION}

We prefer Ender nails as fixation materials in our technique, as they utilize the biomechanical advantages of the nails, thereby resulting in a more rapid treatment process. Because Ender nails are flexible, their proximal tips are anatomically suited to the archshaped structure in the proximal femoral medullary cavity. We can see that this anatomical fit results in a balanced load distribution in the proximal femur; this ability is unmatched by other methods. As Ender nails perform with a three-point principle, reduction and assessment occur more often in the valgus. ${ }^{[16]}$ Furthermore, it was found in Pauwell's biomechanical studies of the hip that flexing momentum is highest in the subtrochanteric area, where the compound force from the femoral proximal in a healthy hip while standing or walking intersects with the long axis of the femoral shaft in this area. ${ }^{[17]}$ These measures show that in platescrew systems such as the Dynamic Hip Screw (DHS), the lever of the flexing force becomes elongated, while in intramedullary nails such as Ender nails, the lever shortens. Thanks to the biomechanical advantages of the Ender nail, it is anatomically possible to carry the loads on the femoral proximal evenly along the femo- ral medullary canal while the load on the unit area in the fractured region is minimal. ${ }^{[18]}$

Despite their advantages, the rotational stability of Ender nails is weak. ${ }^{[10-12]}$ Because the external rotator muscles of the hip force the hip into an external rotation motion, particularly in unstable fractures, we sought to neutralize these muscles for one to two months by adding a unilateral external fixator on neutral rotation to the hip after reduction and assessment with Ender. As the initial valgus reduction in Ender nail use is promising, we expected to stop varus thrust and reduction loss for one to two months through early loading by a few days, using an external fixator. Paley ${ }^{[19]}$ and Kocaoglu's ${ }^{[20]}$ technique combining the use of an external fixator with locked intramedullary nails in elongating long bones motivated us to choose this combination. While the aim of this technique was to comfort the patient by shortening the duration of exposure to the external fixator during elongation, in our surgery, we used the external fixator to support the intramedullary nail. While it might seem best to use only the external fixator, it should only be used in older patients with more serious conditions, given the potential complications. ${ }^{[5,21]}$ Today, dynamic sliding hip nails and proximal intramedullary femoral nails (PFN and Gamma nails) are more commonly used in surgery of intertrochanteric fractures. Although there is no final consensus, DHS nails are mostly used for stable fractures while PFN and Gamma nails are mostly used for unstable fractures. ${ }^{[22]}$ However, proximal intramedullary nails did not yield infallible results either; some complications and failures were reported. . $^{[3,23,24]}$

Rigid plate screws, however, caused complications, including delayed union and non-union, wound infections and implant failure. In addition to bone fragments being devascularized, healing by callus formation is slow in the open reduction with DHS. Postoperative varus collapse, limb shortening and medial displacement of the distal fragment, as critical complications, were reported with DHS, which is one of the most widely used techniques for intertrochanteric fractures. ${ }^{[2,10,16]}$ Furthermore, plate fracture secondary to failure in a bending mode may occur. Intramedullary nails have a biomechanical advantage over DHS due to the fixation device within the medullary canal. The bending moment on it is considerably less than with DHS. However, late femoral fractures at the tip of the device, such as the Gamma nail with short intramedullary stem, or through the distal locking screws have also occurred in 3\% to $6 \%$ of patients. Therefore, the use of long intramedullary nails that end at the supracondylar region of the femur has been advocated. New devices, such as the Ace Trochanteric Femoral Nail and the Trochanteric Femoral Nail have been developed, but the literature on these devices 
is limited. Additionally, the use of an intramedullary device may be precluded in severe deformities of the femoral canal or excessive anterior bowing. ${ }^{[3]}$

Prosthetic replacement for hip fractures may expedite early patient mobilization and ambulation and thereby maximize the patient's functional recovery. ${ }^{[25]}$ While it is an important treatment option for displaced femoral neck fractures, primary prosthetic replacement has had limited use in acute unstable intertrochanteric fractures in elderly patients. In patients with severe osteoporosis with comminution, the prosthesis selected must replace the calcar, with provisions for greater trochanteric reattachment to restore abductor function. However, this requires a more extensive surgical procedure than does internal fixation and entails greater blood loss, longer surgical and anesthetic time, and the potential for more frequent complications, not to mention greater implant cost. ${ }^{[2]}$

The external rotation deformities are certainly more commonly encountered in patients treated with Ender nailing. Although Habernek et al. ${ }^{[9]}$ and Levy et al. ${ }^{[10]}$ found $25 \%$ and $30 \%$ external rotation failure rates, respectively, we encountered only one case $(2.6 \%)$. Habernek et al ${ }^{[9]}$ reported that $40 \%$ of patients experienced leg shortening, but in our study, only two patients $(5.0 \%)$ suffered leg shortening due to varus deformity. Furthermore, Habernek et al. ${ }^{[9]}$ reported that in patients with unstable fractures treated with Ender nails and cerclage wire, weight bearing was not allowed for at least six weeks postoperatively. In contrast, we did not perform any internal fixation and full weight bearing using two crutches or a walker was begun on the second postoperative day.

As for the number of Ender nails, we chose to use 2-3 nails with an anteversion as opposed to the 4-5 Ender nails recommended to fill the medullary cavity completely. ${ }^{[18]}$ In the Ender nail surgery performed in our previous studies, we observed that while the first two nails were sent to the femoral neck with no problem, the sending of the third, fourth, and fifth nails became more difficult. To undo perforations that may occur along the line of fracture of the femoral neck, Waddell ${ }^{[18]}$ suggested that the nails be pulled back and redirected for better assessment. Unfortunately, this prolongs the operation and the duration of X-ray exposure. Moreover, the bone window in the femoral supracondylar area must naturally be opened wider. In the operations we performed using the classic method of filling the medullary cavity completely with Ender nails, we observed that in most cases, additional fissures occurred in the bone window. As a result, one may encounter unexpected complications, including the loss of stability, distal migration of the nails, or an additional supracondylar fracture due to the fissures in the femoral supracondylar region. These potential results contradicted our expectations of more stability.

In our study, we were able to send two Ender nails to the medullary cavity more rapidly by opening a hole in the bone with an awl instead of a window, and by making a 3-4 cm mini-incision in the femoral supracondylar area. Moving along the fracture line in an intramedullary direction, the nails adapt easily to the antreversion angle because they are so few in number in the femoral neck, and because they are flexible, as Pankowich stated. ${ }^{[1]}$ The two or three Ender nails sent to the medullary cavity previously while moving along the Shanz pins of the external fixator were elastic and did not fill the medulla cavity completely. Therefore, they were able to pass through the bone cortex, providing external fixation quite easily.

Despite the limitations of this study, including its retrospective and noncomparative design, we believe that it can contribute to the evaluation of benefits expected from hip surgery for surgeons in trauma centers.

Prospective and randomized comparative studies on hip surgery will definitely provide more conclusive data. However, these would hardly be practicable in such a complex disorder as fractures, especially because of the problems associated with adequate randomization. Therefore, further biomechanical analysis studies are necessary to confirm our findings.

In our analysis, given the several advantages of the Ender nails, the method described above is more stable, successful, effective, anatomically sound, and minimally invasive. Finally, we believe that this technique is an effective one that can be applied easily and rapidly to unstable intertrochanteric fractures.

\section{Conflict of interest}

There is no conflict of interest applicable.

\section{REFERENCES}

1. Egol KA, Koval KJ, Zuckerman JD. Functional recovery following hip fracture in the elderly. J Orthop Trauma 1997;11:594-9.

2. Kenneth JK, Zuckerman JD. Intertrochanteric fractures. In: Bucholz RW, Heckman JD, editors. Rockwood and Green's fractures in adults. Vol. 2, 5th ed. Philadelphia, PA: Lippincott Williams \& Wilkins; 2001. p. 1634-63.

3. LaVelle DG. Fractures and dislocations of the hip. In: Canale ST, Beaty JH, editors. Campbell's operative orthopaedics. Vol 3, 11th ed. Philadelhia: Mosby; 2008. p. 3237-308.

4. Ozkaya U, Parmaksizoğlu AS, Gül M, Kabukçuoğlu Y, Ozkazanli G, Basilgan S. Management of osteoporotic pertrochanteric fractures with external fixation in elderly patients. Acta Orthop Traumatol Turc 2008;42:246-51.

5. Atıcı T, Sahin N, Oztürk A, Yaray O. Treatment of intertrochanteric femur fractures in high-risk geriatric patients $(\geq 65$ years) with external fixation. Ulus Travma Acil Cerrahi Derg 2010;16:413-20.

6. Barrios C, Walheim G, Broström LA, Olsson E, Stark A. 
Walking ability after internal fixation of trochanteric hip fractures with Ender nails or sliding screw plate. A comparative study of gait. Clin Orthop Relat Res 1993;(294):187-92.

7. Berglund-Rödén M, Swierstra BA, Wingstrand H, Thorngren KG. Prospective comparison of hip fracture treatment. 856 cases followed for 4 months in The Netherlands and Sweden. Acta Orthop Scand 1994;65:287-94.

8. Eren OT, Küçükkaya M, Tezer M, Yilmaz C, Kuzgun U. Treatment of intertrochanteric fractures of the femur with Ender nails in patients over the age of 65 years. Acta Orthop Traumatol Turc 2003;37:102-6.

9. Habernek H, Wallner T, Aschauer E, Schmid L. Comparison of ender nails, dynamic hip screws, and Gamma nails in the treatment of peritrochanteric femoral fractures. Orthopedics 2000;23:121-7.

10. Levy RN, Siegel M, Sedlin ED, Siffert RS. Complications of Ender-pin fixation in basicervical, intertrochanteric, and subtrochanteric fractures of the hip. J Bone Joint Surg [Am] 1983;65:66-9.

11. Pankovich AM, Tarabishy IE. Ender nailing of intertrochanteric and subtrochanteric fractures of the femur. J Bone Joint Surg [Am] 1980;62:635-45.

12. Olerud S, Stark A, Gillström P. Malrotation following Ender nailing. Clin Orthop Relat Res 1980:139-42.

13. Ross AF, Tinker JH. Preoperative evaluation of the healthy patient. In: Rogers MC, Tinker JH, Covino BG, Longnecker DE, editors. Principles and practice of anesthesiology. St. Louis, Missouri: Mosby; 1993. p. 3-36.

14. Parker MJ, Palmer CR. A new mobility score for predicting mortality after hip fracture. J Bone Joint Surg $[\mathrm{Br}]$ 1993; 75:797-8.

15. Harris WH. Traumatic arthritis of the hip after dislocation and acetabular fractures: treatment by mold arthroplasty. An end-result study using a new method of result evaluation. J Bone Joint Surg [Am] 1969;51:737-55.

16. Spiegel PG, VanderSchilden J. Subtrochanteric fractures. In: Evarts CM, editor. Surgery of the musculoskeletal system. Vol. 2, 1st ed. New York: Churchill Livingstone; 1983. p. 149-85.

17. Pauwels F. Biomechanics of the normal and diseased hip. Berlin-Heidelberg-New York: Springer-Verlag; 1976.

18. Waddell JP. Subtrochanteric fractures of the femur: a review of 130 patients. J Trauma 1979;19:582-92.

19. Paley D, Herzenberg JE, Paremain G, Bhave A. Femoral lengthening over an intramedullary nail. A matched-case comparison with Ilizarov femoral lengthening. J Bone Joint Surg [Am] 1997;79:1464-80.

20. Kocaoglu M, Eralp L, Kilicoglu O, Burc H, Cakmak M. Complications encountered during lengthening over an intramedullary nail. J Bone Joint Surg [Am] 2004;86-A:2406-11.

21. Kazakos K, Lyras DN, Verettas D, Galanis V, Psillakis I, Xarchas K. External fixation of intertrochanteric fractures in elderly high-risk patients. Acta Orthop Belg 2007;73:44-8.

22. Schipper IB, Marti RK, van der Werken C. Unstable trochanteric femoral fractures: extramedullary or intramedullary fixation. Review of literature. Injury 2004;35:142-51.

23. Williams WW, Parker BC. Complications associated with the use of the gamma nail. Injury 1992;23:291-2.

24. Ongkiehong BF, Leemans R. Proximal femoral nail failure in a subtrochanteric fracture: The importance of fracture to distal locking screw distance. Injury Extra 2007;38:445-50.

25. Altay MA, Ertürk C, Işıkan UE. Bipolar hemiarthroplasty for the treatment of femoral neck fractures and the effect of surgical approach on functional results. Eklem Hastalik Cerrahisi 2010;21:136-41. 